\title{
Challenges for Teacher Profession in Contemporary Indonesia: A Regulatory Analysis
}

\author{
Saru Arifin \\ Universitas Negeri Semarang, Indonesia \\ saruarifin@mail.unnes.ac.id
}

\begin{abstract}
The Indonesian government shows the commitment to include teachers as a noble profession by enacting the Act on Teacher and Lecturer in 2014. This Act outlines and protects the teaching profession so that teachers are expected to be able to work safely and comfortably in carrying out their professional duties. However, the way to strengthen this teacher profession does not respond to many cases resulting in teacher insecurity and discomfort in carrying out the profession. Teachers often experience various considerable threats of violence and intimidation from students, parents, and community members. This paper will discuss the legal protection for teachers in carrying out their profession. The discussion includes the factors that often cause teachers to face criminal limits and strengthen legal protection for teachers in carrying out their noble profession.
\end{abstract}

KEYWORDS: Legal Protection, Teacher Profession, Educational Policies.

Copyright $\odot 2020$ by Author(s)

This work is licensed under a Creative Commons Attribution-ShareAlike 4.0 International License. All writings published in this journal are personal views of the authors and do not represent the views of this journal and the author's affiliated institutions.

\section{HOW TO CITE:}

Arifin, Saru. "Challenges for Teacher Profession in Contemporary Indonesia: A Regulatory Analysis" (2020) 7:2 Lentera Hukum 117-136.

Submitted: May 05, 2020 Revised: June 20, 2020 Accepted: July 07, 2020 


\section{INTRODUCTION}

Cases of violencel against teachers ${ }^{2}$ are increasingly common in various schools, at various levels of the education unit, and in many places, both in cities and villages. Threats and acts of violence against teachers come in many forms, ${ }^{3}$ some of which are verbal, physical violence, psychological intimidation, and also lawsuits. These various conditions and situations will undoubtedly have a severe impact on the comfort and independence of the teacher in carrying out his profession. The impact of further determinants is the decline of the authority of teachers, ${ }^{4}$ schools, and also the quality of education and students. This situation is vastly different from in the past, where the teacher becomes a respected, respected, and feared role model by students. The Indonesian Child Protection Commission (KPAI) $)^{5}$ suspects that the problem of student character that is not well developed from the family environment and on the other hand, the low ability of teacher pedagogy is a factor causing teacher violence against students or vice versa.

Article 14 of Act Number 14 of 2005 on Teacher and Lecturer has explicitly provided several guarantees for the protection of the teaching profession, such as legal protection, professional protection, welfare protection, security, and comfort. As

1 In the Indonesian General Dictionary, violence is defined as "hard nature or thing; strength; coercion. Whereas "coercion means pressure, firm pressure. These words are synonymous with the word "rape," which means to subdue with violence; overpower; force with violence and violate with violence." Therefore, violence means to bring strength, coercion, and pressure. In English, violence is called violence. Violence is closely related to the combination of the Latin words "vis" (power, strength) and "latus" (which comes from Ferre, carrying), which means to bring strength. See Johan Galtung, Kekuasaan dan Kekerasan, (Yogyakarta: Kanisius, 1992) at 62. Elliot, Hamburg, and Wiliam define violence as a form of attitude, behavior in the form of threats, intimidation that makes others suffer. According to Jack D Douglas and Frances Chault Waksler, the term violence is used to describe the behavior of using force to others openly (overt) or close (covert), both offensive or defensive. See in Abdurrahman Assegaf. Pendidikan Tanpa Kekerasan: Tipologi, Kondisi, Kasus dan Konsep, (Yogyakarta: Tiara Wacana Yogyakarta, 2004) at 39.

2 Violence against teachers is one of the new trends in violence that generally occurs in the educational environment. Many factors cause violence in the educational environment, such as the provision of physical law to an offense, poor school governance policies, the influence of the community and media environment, changes in the community's social situation, and the background of the perpetrator's violence. See Abd. Rachman Assegaf, et al., Kondisi dan Pemicu di Lingkungan Pendidikan. (2003) 2:1 IstiQRO', at 38-39.

3 There are three forms of violence, the first is a form of verbal violence, such as giving a disliked nickname, calling by the name of a parent, and calling by another name that is not appropriate, giving a label by saying 'lazy,' 'stupid,' and 'naughty.' A second form is psychological violence, such as ignoring or not caring, and throwing out words whose purpose is threatening or intimidating, such as 'watch out for you.' Furthermore, the third form is physical violence, such as tweaking, hitting, and pushing the head. See Tamsil Muis, Muhammad Syafiq, and Siti Ina Savira, Form, Causes, and Impact of Teacher Violence Against Students in Teaching and Learning Interactions from Student Perspectives at Surabaya City Junior High School: A Survey, (2011) 1:2 Jurnal Psikologi Teori dan Terapan, at 71.

4 For an authority teacher, it is necessary because that authority is built with compassion, not violence. However, while students have exceeded the limits, the sanctions should adjust to the severity of their mistakes. See Rurrotul Ainiyah, Pandangan Masyarakat Terhadap Kekerasan Dalam Pendidikan Terkait Dengan Konsep Tawadhu' Terhadap Guru di MTs An Namirah Tanah Merah Bangkalan, (2013) Undergraduate Thesis UIN Sunan Ampel Surabaya.

5 Beritagar.id, 2 Faktor Penyebab Kekerasan di Sekolah Menurut KPAI, (2019), online: 〈https://beritagar.id/artikel/berita/2-faktor-penyebab-kekerasan-di-sekolah-menurut-kpai〉. 
stakeholders, the protection obligation for teachers is carried out jointly between the Central Government, Regional Governments, and the community. However, unfortunately, on a practical level, the various types of protection do not work as they should, as demonstrated by the various cases of violence experienced by teachers as described above. As a result, teachers become inferior themselves in carrying out these professional tasks.

Data from various cases of violence faced by teachers indicates that the violence generally occurs in the form of excessive reactions from students and parents of students to teachers' actions in carrying out their teacher assignments, such as teaching and character education. However, teachers that get excessive reactions do not get adequate legal protection from both the school and the government. This situation makes teachers nervous in carrying out their teacher tasks.

Previous studies confirmed that teachers today face a dilemma when they want to enforce discipline to their students. They are hesitant or awkward to do this in front of their students, feared to be blamed by law. However, on the other side, they must do that as a part of character education. This dilemma situation, at some points, triggered by the enactment of Child Law Number 23/2014, which strictly protects children from any form of violence. ${ }^{6}$ However, Assegaf in his study argues, that violation in the life of education could happen caused by one of these three factors, namely: the enforcement of disciplinary rules for particular misconduct by a student; violence due to the worse of education management; and violence triggered by the social environment which is viral by the mass media, including social media. ${ }^{7}$

To these situations, teachers that remain to use the physical method to discipline students have their own arguments. They argue that their obligation is not only to transfer knowledge but also to teach students character. It is referred to as a quote, "to educate a person in mind, not in heart, to educate a menace to society." Thus, educating students solely on the aspect of knowledge that exempts the heart may be parallel to educating students to be wolves for the community.

This paper will discuss the various legal issues related to the teaching profession, especially teachers dealing with the law in carrying out the teaching profession's task. The first part is an introduction that captures the general background of the writing of this paper. The second part will discuss the legal framework for protecting the teacher profession, followed by an analysis of the factors that cause teachers to be forced to deal with the law. The next discussion is related to how the legal protection for teachers and the strategy to strengthen the protection implementation for teachers in conducting their profession, and then this paper ends with a conclusion.

\footnotetext{
6 Agus Affandi, 'Dampak Pemberlakuan Undang-Undang Perlindungan Anak Terhadap Guru Dalam Mendidik Siswa', Jurnal Hukum Samudra Keadilan, (2016) 11:2 Jurnal Hukum Samudra Keadilan, at 196-208.

7 Abd Rachman Assegaf, Kondisi Dan Pemicu Kekerasan Dalam Pendidikan, (2003) 2:1 Istiqro, at 37-54.
} 


\section{LEGAL FRAMEWORK FOR PROTECTING TEACHER PROFESSION}

The conception of legal protection contains a comprehensive understanding. In legal protection, there is a recognition of the rights of individuals who are protected. It also includes a guarantee of protection of these rights from arbitrary actions from outsiders or authorities. ${ }^{8}$ Besides, in the conception of the protection contained the meaning of providing security and comfort guarantees both physically and psychologically ${ }^{9}$ for an individual to enjoy the rights. In the conception of legal protection, the implementation phase is divided into two, ${ }^{10}$ viz. preventive ${ }^{11}$ and repressive ${ }^{12}$ legal protection.

In this regard, teacher ${ }^{13}$ as an important figure in the preparation of the nation's future generation, it has to be well prepared. Regarding this, the state requires that persons with this profession must be professional people ${ }^{14}$ in teacher training. In the provision of Article 39 of Law Number 14/2005 concerning Teachers and Lecturers, in paragraph (1), it is stated that the national and regional governments, community, professional organizations, and/or education units are required to protect teachers in carrying out their duties. This provision shows the state's seriousness to provide comprehensive protection to teachers conducted by all levels of government and associations. The types of protection provided to teachers are also very comprehensive, including legal protection, professional protection, and protection of occupational safety and health. This provision clearly distinguishes the difference between legal protection, professional protection, occupational safety protection, and occupational health protection. The difference in protection is related to the scope regulated or given protection for each type of protection so that it makes it easier to assess.

8 Setiono, Rule of Law (Supremasi Hukum). (Surakarta: Magister Ilmu Hukum Program Pascasarjana Universitas Sebelas Maret, 2004) at 3

9 Satijipto Raharjo, Ilmu Hukum, (Bandung: PT. Citra Aditya Bakti, 2000) at 74.

10 Phillipus M. Hadjon, Perlindungan Hukum Bagi Rakyat Indonesia, (Surabaya: PT. Bina Ilmu, 1987) at 2.

11 Protection provided by the government to prevent before the occurrence of violations. It is contained in the legislation to prevent a violation and provide guidelines or restrictions in carrying out obligations. See Muchsin, Perlindungan dan Kepastian Hukum bagi Investor di Indonesia, (Surakarta: Magister Ilmu Hukum Program Pascasarjana Universitas Sebelas Maret, 2003) at 20.

12 Repressive legal protection is the ultimate protection in the form of sanctions such as fines, imprisonment, and additional punishment given if a dispute has occurred or a violation has been committed. Ibid.

13 The teaching profession based on the Teacher and Lecturer Law is an activity carried out accompanied by high dedication, or wholeheartedly, which "involves both inner and inner potential in implementing it and achieving its goals, without being fixed on time and opportunity. As the philosophy "digugu dan ditiru" and "teacher pee standing pupils pee running" For that reason in giving the teacher professional award, the law provides appropriate mandate as a source of income for life. See Harun, Perlindungan Hukum Profesi Guru Dalam Perspektif Hukum Positif, (2016) 1:1 Jurnal Law and Justice, at 76.

14 Professional understanding in the Teacher and Lecturer Law is interpreted as "work or activities carried out by a person and a source of income for life that requires expertise, skills, or skills that meet certain quality standards or norms and require professional education." Ibid. Provisions regarding juridical parameters regarding teacher professionalism can be seen in Article 7-ll Law on Teacher and Lecturer. 


\section{TEACHER DEALING WITH LAW}

Three things that trigger cases of violence that often happen to teachers are physical, non-physical, and legal. They are acts of violence against teachers caused by acts of violence that are purely violence, violence caused by immoral acts committed by unscrupulous teachers, and acts of violence caused by using disciplinary methods of students that contain nuances of violence.

\section{A. Acts of Physical Abuse}

Studies on violence in education show that violence against students is more dominant than violence against teachers as objects. For instance, the study of the Indonesian Child Protection Commission (KPAI) ${ }^{15}$ concludes that of one hundred cases of violence in the first half-year of 2018, 50\% of them were violence against elementary school students, followed by high school (34.7\%) and junior high school (19.3\%). According to the Chairman of the Indonesian Independent Teachers Federation, ${ }^{16}$ Tetty Sulastri, so far, the teacher is still often arguing about enforcing discipline when committing violence against students. Therefore, it is not surprising that as many as 90\% of teachers reject child-friendly school campaigns by saying, in practice teaching and learning full of tenderness, discipline will not arise.

In practice, violence against students by the school is often carried out in the name of discipline even though it is violent. According to data from KPAI, ${ }^{17}$ violence in educational institutions involves teachers or principals, students, and parents of students. The culprit is a teacher of six sports teachers, two religious teachers, one art teacher, one computer teacher, one social studies teacher, and four Primary School grade 4 teachers.

If observed, the teacher's physical harm to students by kicking or hitting students occurs due to the teacher's emotional impulse towards the student, which is accumulative. For example, the case of Teacher Tursidi Karyo, ${ }^{18}$ which was quite viral in the mass lines, frankly he was forced to commit physical violence against his students because he saw the student's track record often lying, acting in front of all the teachers and not being honest so that the teacher Tursidi had felt an accumulation of "anger" against the student, so he reflexively abused the students.

15 See the full report on the cases at KPAI. Data Kasus Perlindungan Anak Berdasarkan Lokasi Pengaduan Dan Pemantauan Media Se-Indonesia Tahun 2011-2016. (2016) Series. 〈https://bankdata.kpai.go.id/tabulasi-data/data-kasus-se-indonesia/data-kasus-perlindungan-anakberdasarkan-lokasi-pengaduan-dan-pemantauan-media-se-indonesia-tahun-2011-2016>.

16 BBC.com, Kekerasan Terhadap Siswa Masih Marak, Guru Berdalih 'Demi Kedisiplinan', (2018), online: < https://www.bbc.com/indonesia/indonesia-44925805).

17 Tempo.co, KPAI: Kekerasan di Dunia Pendidikan Mencapai 127 Kasus, (2019), online: 〈https://nasional.tempo.co/read/1266367/kpai-kekerasan-di-dunia-pendidikan-mencapai-127kasus/full\&view=ok .

18 Merdeka.com, Guru SMPN 10 Yogyakarta Mengaku Emosi dan Spontan Tendang Siswanya, (2019), online: 〈https://www.merdeka.com/peristiwa/guru-smpn-10-yogyakarta-mengaku-emosi-dan-spontantendang-siswanya.html>. 
Another case of violence that had a traumatic impact on students was in the case of RM, ${ }^{19}$ a teacher at SD Negeri No. 104302 in Cempedak Lobang, Sei Rampah, Serdang Bedagai Regency, North Sumatra, who punished a student in an appropriate manner by licking the bathroom floor 12 times because he did not bring compost. The teacher asked his students to bring compost land as an assignment for skills subjects. Just four times doing his sentence, the student was vomiting so that he had trauma. At the same time, the parents are angry and devastated, and it is often that the student's father comes to school and asks the teacher to impose sanctions.

\section{B. Immoral actions}

In many cases, violence experienced by teachers is a reaction from parents or the community to immoral acts committed by unscrupulous teachers. For example, sexual harassment of students or their students. It considers the KPAI ${ }^{20}$ report, which states that during the first semester of 2019, it was known that sexual violence perpetrated by teachers and principals against students occurred in primary school with eight cases and junior high schools as many as three cases. Of these cases, nine cases of sexual violence made girls victims. Furthermore, the rest, the victims are boys.

Initially, cases like this arose because of violations of the teacher's code of ethics by unscrupulous teachers carrying out relationships or interactions with students. The boundary line between teacher and student turns into an intimate relationship. Ironically, in many cases, the violation is mostly used by intimidating methods towards students. As a result, students are in a weak bargaining position, without any ability to fight. Thus, sexual violence also often occurs against students, which includes in the government and Islamic schools.

Violations of the teacher's code of ethics ${ }^{21}$ by unscrupulous teachers as an entry point for the occurrence of these criminal actions should be a serious concern by the teacher professional association. The code of ethics is an instrument of control over the teaching profession's morale that is supposed to be intrinsic in every teacher's self. However, teachers, as ordinary people, often face various temptations that come from many causes. Therefore, the professional teacher association must design the concept of strengthening the teacher's code of ethics, especially in monitoring its implementation. Teachers' code of ethics is not enough to be read-only at ceremonial meetings or

19 Beritagar.id, Ketika Guru Menyuruh Murid Menjilat Kamar Mandi, (2018), online: 〈https://beritagar.id/artikel/berita/ketika-guru-menyuruh-murid-menjilat-kamar-mandi〉.

20 Suara.com, KPAI: Pelaku Kekerasan Seksual ke Siswa Didominasi Guru dan Kepala Sekolah, (2019), online: 〈https://www.suara.com/news/2019/06/30/214134/kpai-pelaku-kekerasan-seksual-ke-siswadidominasi-guru-dan-kepala-sekolah».

21 Article 2 of the Teacher Code of Ethics states: (1) The Code of Ethics for Indonesian Teachers is a guide to attitudes and behavior aimed at placing teachers respectable, noble, and dignified profession that is protected by law. (2) The Indonesian Teachers' Code of Ethics functions as a set of moral principles and norms that underlie the implementation of professional duties and services of teachers concerning students, parents or guardians of students, schools and professional colleagues, professional organizations, and the government under religious values, education, social, ethics, and humanity. 
association meetings regularly, but continuous and measurable efforts are needed to improve teachers' quality of compliance.

\section{Enforcement of discipline}

The teacher's task teaches the sciences to students and educates their character, including providing penalties if needed. The teacher's right to impose sanctions on students is protected by the law as long as it aims to enforce the law on the student's violation conduct on religious norms, norms of decency, norms of decency, written or unwritten rules set by teachers. The penalties can be enforced to a student that breaks the regulations set by the school or the general guidelines on the learning process made by the government. 22

"Sanctions can be in the form of reprimands and/or warnings, both oral and written, as well as penalties that are educational under the educational method, the code of ethics of teachers, and legislation."

The formulation of the legal norms above deals with freedom. The teacher has the freedom to apply measures to several violations committed by students, from violations of school rules to personal violations, such as morals and religion. The enforcement of discipline in schools is generally carried out by teachers in the form of punishment. The type of punishment for disciplining students considered to violate school rules, not working on assignments, and student behavior that deviates from the school's character values varies. Some use soft penalties, such as social work, by cleaning up certain parts of the school or giving an additional burden of obligations in lessons, such as doing assignments, memorizing specific lessons, or writing statements not to repeat a certain amount of mistakes. Another type of punishment that is harsh is physical punishment. Then, it often confronts teachers with laws or violent backlash from students or parents of students.

The main point in giving harsh punishment through physical punishment in different terms is called "corporal punishment." In its history, corporal punishment has been used by many schools in various countries as one of the methods that are considered useful in upholding the discipline, values, and character of students to get back to the way they should be. The granting of physical punishment to students who deviate in the next development experienced widespread dynamics and controversy, both among the government, observers of education, and education experts. Some critical questions related to the debates surrounding physical punishment, such as the provision of physical punishment for students who violate or disorder effective in returning students to the path of proper behavior? Is giving physical punishment to students able to internalize moral values to students? Does physical punishment for students change student behavior? Furthermore, is the physical punishment the same as physical abuse?

22 See Article 39 paragraph (1) and paragraph (2) Government Regulation Number 74/2008 on the teacher. 
These questions have very different answers among supporters and opponents of physical punishment to students. For example, Bourke ${ }^{23}$ stressed that giving physical punishment to students must be intended in the context of establishing discipline, ${ }^{24}$ control or correction of student behavior-and by taking into account the conditions of their students in terms of age and gender. ${ }^{25}$ Bourke's view represents support for granting conditional physical punishment. It is also reinforced by the argument that emphasizes the difference between physical punishment and physical abuse that aims to "injure" the physical student. However, some experts assert that it is very likely that physical punishment will escalate into physical abuse on students. Therefore, Gudyanga ${ }^{26}$ suggested that the use of physical punishment for students as much as possible be used as the most recent method if other methods can be used or are ineffective. However, the UN strongly recommends that through child protection conventions, the UN calls for physical punishment to be excluded from the rules of punishment. In the US, although this country still leaves at least 21 states that still use physical punishment methods for students, it has generally begun to be eliminated with social punishment-believed to be more positive in building students' skills and character. $^{27}$

\section{LEGAL PROTECTION FOR TEACHERS}

Changes in the social and legal situation related to teacher relations with students at this time bring a dilemma consequence for teachers, especially in upholding student discipline. If, in the past, the use of the method of physical punishment was considered normal and not a problem, then in the present time it is very problematic, both because the legal system is related to child protection and the influential role of social media to proclaim a case of violence.

In the legal context, for example, some cases of violence against students, teachers generally get a counter-reaction, both from students' parents and the community, and some of them are lawsuits as a solution. Against this circumstance, teachers often

23 Bourke, J.P., Bourkes' Criminal Law, (Sydney: Butterworth's, 1981) at 53.

One of the goals of student discipline is to improve their character. It has also been strengthened by the support of the American Supreme Court on this viewpoint. However, some experts then oppose it, that belief is only a myth because no data proves the relationship between physical punishment with an increase in student character. Likewise, it aims to get respect from students. That cannot be done with violence, but rather with respect and affection for students ${ }^{24}$. See R. A. Dubanoski, Inaba, M., \& Gerkewicz, K., Corporal Punishment in Schools: Myths, Problems, and Alternatives. Child Abuse \& Neglect, (1983) $7: 3$, at 272 .

25 The practice of physical punishment in Egypt, for example, for boys is carried out on the head, face, thighs, and buttocks using hands, rattan, and shoes. However, since 1971 Egypt, through the Ministry of Education, officially has banned the use of physical punishment to students. See Youssef, R. M., Attia, M. S.-E.-D., \& Kamel, M. I., Children Experiencing Violence II: Prevalence and Determinants of Corporal Punishment in Schools. Child Abuse \& Neglect, (1998) 22:10, at 981.

26 E. Gudyanga, Corporal Punishment in Schools: Issues and Challenges, (2014) 5:9 Mediterranean Journal of Social Sciences, May.

27 David R. Dupper, Amy E. Montgomery Dingus, Corporal Punishment in U.S. Public Schools: A Continuing Challenge for School Social Workers, (2008) 30:4 Children \& Schools, at 247. 
'stutter' in applying student discipline, especially when using physical punishment because of the freedom of sanction sanctions. It is guaranteed in Government Regulation Number 74/2008 concerning Teachers is considered to conflict with the provisions of Article 54 of Law Number 35 of 2014 concerning Amendments to Law Number 23/2002 Concerning Child Protection, and several human rights regulations both at national and international levels that tend to protect children from all forms of violence, especially in the educational environment, as shown in Table 1 below.

Table 1

Freedom of Punishment for Students Vs Protection of Child Violence

\begin{tabular}{|c|c|}
\hline Gov Reg 74/2008 on Teacher & $\begin{array}{c}\text { Law 35/2014 revising Law 23/2002 } \\
\text { on Child Protection }\end{array}$ \\
\hline $\begin{array}{l}\text { Article } 39 \text { paragraph (l) and paragraph (2): } \\
\text { 1. Teachers have the freedom to impose } \\
\text { sanctions on their students who violate } \\
\text { religious norms, norms of decency, norms of } \\
\text { decency, written or unwritten rules set by } \\
\text { teachers, regulations on the level of education } \\
\text { units, and statutory regulations in the learning } \\
\text { process under their authority. } \\
\text { 2. These sanctions can be reprimanded and/or } \\
\text { warnings, both oral and written, and penalties } \\
\text { that are educational by the educational method, } \\
\text { the code of ethics of teachers, and legislation. }\end{array}$ & $\begin{array}{l}\text { Article 54: } \\
\text { l. Children within and within the } \\
\text { education unit must obtain protection } \\
\text { from acts of physical, psychological } \\
\text { violence, sexual crimes, and other crimes } \\
\text { committed by educators, instructional } \\
\text { staff, fellow students, and/or other } \\
\text { parties. } \\
\text { 2. Protection, as referred to in paragraph } \\
\text { (1), shall be carried out by educators, } \\
\text { educational staff, government officials, } \\
\text { and/or the public. }\end{array}$ \\
\hline $\begin{array}{l}\text { Article 40: } \\
\text { Teachers are entitled to protection in carrying } \\
\text { out their duties in the form of a sense of security } \\
\text { and security guarantees from the national and } \\
\text { regional governments, educational units, } \\
\text { professional teacher organizations, and/or the } \\
\text { community under their respective authorities. }\end{array}$ & $\begin{array}{l}\text { Article 76C: } \\
\text { Everyone is prohibited from placing, } \\
\text { letting, doing, ordering to do, or } \\
\text { participating in violence against children. }\end{array}$ \\
\hline $\begin{array}{l}\text { Article 4l: } \\
\text { Teachers are entitled to legal protection from } \\
\text { acts of violence, threats, discriminatory } \\
\text { treatment, intimidation, or unfair treatment on } \\
\text { the part of students, parents of students, the } \\
\text { public, bureaucracy, or other parties. }\end{array}$ & $\begin{array}{l}\text { Article 80: } \\
\text { 1. Every person who violates the } \\
\text { provisions as referred to in Article } 76 \mathrm{C} \\
\text { shall be sentenced to a maximum } \\
\text { imprisonment of three years for six } \\
\text { months and/or a maximum fine of IDR } \\
72,000,000.00 \text {. } \\
\text { 2. In the case of a child, as referred to in } \\
\text { paragraph (1) seriously injured, the } \\
\text { perpetrator shall be sentenced to a } \\
\text { maximum imprisonment of five years } \\
\text { and/or a maximum fine of IDR } \\
100,000,000.00 \text {. }\end{array}$ \\
\hline
\end{tabular}




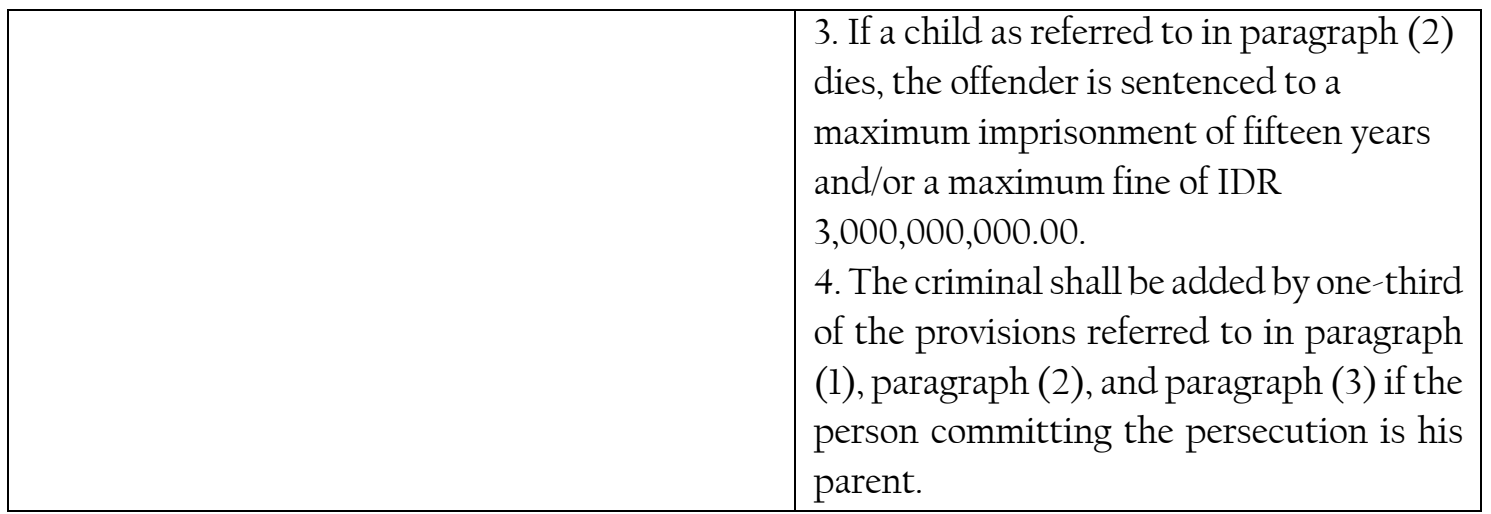

In general, the teacher's stuttering in providing physical punishment is triggered by the criminal threats set out in Article 80 of Law No. 35 of 2014, like the case of a teacher named Muhammad Samhudi. ${ }^{28}$ The Public Prosecutor prosecuted him for six months of imprisonment with one-year probation because he was considered guilty and violated Article 80 paragraph (1) of the Child Protection Act. However, whether such understanding is correct means legal experts expressly state that such an understanding will be wild and make teachers traumatized and worried about carrying out their professional duties in teaching. Two criminal law theories can clearly explain the criminal liability of the teacher's actions in upholding discipline against students.

\section{A. Teacher Discipline Acts cannot be penalized for justification}

In the case of teachers dealing with law, ${ }^{29}$ Muzdakir ${ }^{30}$ states that taking analyses of the case substance is essential to determine the kind of law issue which can be addressed to the teacher. According to criminal law, think that should be seen first is what the teacher's intentions and objectives are. If the hit intends for abuse, it can be a criminal offense. However, if it aims to educate, it should be resolved through family channels, and there is no need to go to court, there is a board of teachers at the school who can complete it. Muzakir further explains that the rise of teachers being convicted should be examined on a case by case basis. If the law is interpreted with the positive law sense, it can backfire for teachers. He suggests that parents should also be able to control their

28 Simomot, Kisah Lengkap Guru Muhammad Samhudi Diadili Gara-Gara Ada Bekas Cubitan di Lengan Muridnya, (2016), online: 〈https://simomot.com/2016/07/01/kisah-lengkap-guru-muhammad-samhudi-diadiligara-gara-ada-bekas-cubitan-di-lengan-muridnya-2/> and Liputan6.com, Samhudi Guru Cubit Murid Tetap Mengajar, (2016), online: 〈https://www.liputan6.com/regional/read/2578217/samhudi-guru-cubitmurid-tetap-mengajar>.

29 Recent cases reported that violence to teachers happened in two different cities that are in Jakarta, and Madura showed the kind of violence experienced caused by first of impolite conduct of students who recorded teacher's activities in the class without his permission. The other case was caused by teacher discipline enforcement to students who perceived broke the discipline. See in Dasma Alfriani Damanik, Kekerasan Dalam Dunia Pendidikan: Tinjauan Sosiologi Pendidikan, (2019) 5:1 Jurnal Sosiologi Nusantara, at 7790.

30 Brillio.net, Benarkah Guru Pukul Murid itu Melanggar Undang-Undang? Ini Jawabannya, (2016), online: 〈https://www.brilio.net/serius/benarkah-guru-pukul-murid-itu-melanggar-undang-undang-inijawabannya-160812f.html> 
emotions and be wiser when their children experience violence at school. Concerns that arise if a child's complaint is swallowed.

The Criminal Law expert's statement clearly underlines that violence against students if it is a form of punishment is not intended as physical harm, then it cannot be processed by Article 74C and Article 80 of Law No. 35 of 2014 Child Protection. There is no explanation of the exceptional nature of Article $74 \mathrm{C}$, for example, due to disciplinary reasons for students. The spirit of the Children's Law is to eliminate all forms of violence in the educational environment. ${ }^{31}$ Therefore, the same understanding between law enforcers is needed in understanding the text and context of the two laws, so that they can be protected from one another.

Concerning this assumption, it is theoretically possible for teachers not to be held liable criminally in upholding discipline against students because of criminal penalties. The elimination of this crime is the elimination of the unlawful nature of an act and the reason for forgiveness, which eliminates mistakes. Based on this, a teacher who disciplines students within certain limits and in educational goals cannot always be accounted for (convicted), even though formally, the teacher has committed acts against the law (criminal acts). It is because there is a justification that accompanies his actions, namely reasons that eliminate the unlawful nature of an act. In this case, known as the principle of nature against material law. ${ }^{32}$

Barda Nawawi, an Indonesia's criminal law scholar, argues that this material nature is against the unwritten law or the law that lives in the community, ${ }^{33}$ so that in this context, the law is not interpreted as "wet", but the law as "recht"34. Therefore, the material loss of lawlessness from the teacher's disciplinary action against the student must be based on customary practices recognized in the teaching profession. In Dutch legal terms, the teacher's actions are known as "Tuchstraf 35 which is a disciplinary punishment aimed at establishing order among certain people. However, the teacher's disciplinary action must be enforced within specified limits. According to Barda Nawawi, ${ }^{36}$ there are three conditions to meet the Tuchstraf qualifications, inter alia, carried out under forced conditions, limited suffering (must be with specific considerations), and is used to achieve the objectives allowed. The reasons for this

31 Margaretha Hanita, et al., Pencegahan Kekerasan Terhadap Anak di Lingkungan Pendidikan, (Jakarta: Pusat Pelayanan Terpadu Pemberdayaan Perempuan dan Anak (P2TP2A), 2009).

32 Rusmilawati Windari, Penggunaan Hukuman Disiplin di Lingkungan Sekolah dalam Perspektif Hukum Pidana Indonesia, (2015) 4:3 Jurnal Hukum Prioris, at 322-323.

33 Ibid.

34 Wet adalah Undang-Undang dalam arti formal, yaitu penetapan dalam bentuk UU yang dibuat oleh Pemerintah bersama-sama DPR yang mengikat secara umum kepada masyarakat yang disertai dengan sanksi. Sedangkan recht adalah keseluruhan peraturan-peraturan, norma-norma hukum dari kehidupan masyarakat. Martias G.I.R.M, Pembahasan Hukum: Penjelasan Istilah-Istilah Hukum BelandaIndonesia, (Jakarta: Ghalia Indonesia, 1969) at 232 and 178.

35 Ibid at 206.

36 Barda Nawawi Arief, Konsepsi Ajaran Sifat Melawan Hukum Materiel dalam Hukum Pidana, (2004) Makalah Seminar Nasional di Hotel Patrajasa, Semarang, 6-7 May. 
justification by Indrianto Seno Adji added, ${ }^{37}$ that the act of disciplining a teacher could lose its unlawful nature when the act was carried out on the following grounds. First, the action has a real purpose that provides benefits to the legal interests that would be protected by lawmakers. Second, protect a legal interest that is higher than the legal interest intended by the formulation of a criminal offense that is violated. Third, it has a higher value for the interests of society compared to self-interest.

\section{B. Sanctioning Teacher's Efforts for Disciplinary Measures}

In contrast to the Tuchstraf concept previously described, in the theory of loss and benefit, the teacher's disciplinary action towards students and its nature cannot be eliminated particularly when the teacher's actions neglect the students' interests and ignore the principle of proportionality between the benefits and losses felt by students. For example, the punishment of children by hitting them with wood resulting in injuries or punish students standing in the field in the hot sun until they faint. ${ }^{38}$ With regard to these two different legal views, to consider whether the teacher's punishment to a student aims for discipline through the provision of physical punishment or whether there is an element of intentional physical injury, it must be clearly proven.

Doriane Lambelet Coleman, et al., ${ }^{39}$ based on the results of her analysis of the court's decision, illustrates the clear difference between physical punishment and physical injury or torture with the following parameters:

Table 2

Physical Punishment vs. Physical Injury

\begin{tabular}{|l|r|l|}
\hline \multirow{2}{*}{ Elements } & \multicolumn{2}{|c|}{ Violent Conception } \\
\cline { 2 - 3 } $\begin{array}{l}\text { l. severity of } \\
\text { injury }\end{array}$ & $\begin{array}{r}\text { Physical Punishment } \\
\text { Physical violence does not cause } \\
\text { physical injury }\end{array}$ & $\begin{array}{l}\text { Resulting in the child suffering } \\
\text { physical injuries, both mild and } \\
\text { severe }\end{array}$ \\
\hline $\begin{array}{l}\text { 2. the age and } \\
\text { development } \\
\text { stage of the } \\
\text { child }\end{array}$ & $\begin{array}{r}\text { The degree of physical } \\
\text { punishment given is very } \\
\text { concerned about the age and } \\
\text { gender of the child }\end{array}$ & $\begin{array}{l}\text { Violence is carried out regardless of } \\
\text { the age and gender of the child }\end{array}$ \\
\hline $\begin{array}{l}\text { 3. Manner of } \\
\text { Discipline }\end{array}$ & $\begin{array}{r}\text { The frequency of punishment is } \\
\text { not much and does not use } \\
\text { violence }\end{array}$ & $\begin{array}{l}\text { Frequency often and also uses tools } \\
\text { (not bare hands), such as repeatedly } \\
\text { beating and injuring the child. }\end{array}$ \\
\hline $\begin{array}{l}\text { 4. emotional and } \\
\text { developmental } \\
\text { effects }\end{array}$ & $\begin{array}{r}\text { Does not cause physical or non- } \\
\text { physical (traumatic) } \\
\text { consequences }\end{array}$ & $\begin{array}{l}\text { Resulting in physical injury and also } \\
\text { has a psychological impact on the } \\
\text { child. }\end{array}$ \\
\hline
\end{tabular}

37 Indriyanto Seno Adji, Asas Perbuatan Melawan Hukum Materiel dan Masalahnya dalam Perspektif Pidana di Indonesia, (2004) Makalah Seminar Nasional Tentang Asas-Asas Hukum Pidana Nasional, Semarang, 26-27 May.

38 Rusmilawati, supra note 32 at 325.

39 Doriane Lambelet Coleman et al., Where and How to Draw the Line Between Reasonable Corporal Punishment and Abuse, (2010) 73 Law and Contemporary Problems 107-166, at 130-135. 


\begin{tabular}{|l|r|r|}
\hline $\begin{array}{l}\text { 5. Perpretrator's } \\
\text { motivation }\end{array}$ & $\begin{array}{r}\text { Discipline, educate, control and } \\
\text { improve }\end{array}$ & $\begin{array}{r}\text { Deliberately hurting and making } \\
\text { children hurt. }\end{array}$ \\
\hline
\end{tabular}

Several parameters mentioned above distinguish the two types of violence. It becomes a standard that needs to adopt in the teacher code of ethics, which must also be understood by all relevant elements, both public enforcement officials, parents of students, government, and schools, so as not to cause problems for teachers in carrying out their profession as a teacher. ${ }^{40}$

\section{STRENGTHENING THE PROTECTION FOR TEACHERS}

Article 39 of Government Regulation Number 74/2008 on Teacher gives the granting of physical punishment to students as one of the methods of education in Indonesia, but due to factors of the culture in education from the past that continues to this day, ${ }^{41}$ it faces a contradict perception, which is sadly not clearly explained to society. Finally, this method of physical punishment now backfires on teachers, which is why they get violent reactions and are even forced to deal with the law. Perhaps the question arises, why is this situation easy for teachers? Isn't that a common thing in the past, and there is no backlash from students or parents, let alone sue it through legal channels?

\section{A. Human Rights}

The strengthening of human rights values in the life of the nation and state through the amendment of the 1945 Constitution since 2009 also coincides with the enactment of Law No. 39 of 1999 concerning human rights then followed by the drafting of several other specific human rights regulations, such as the Law on the Protection of Women and Children. These various human rights regulations provide a new perspective on relationships and the treatment of children in particular. Children in a child's rights regime should be developed in a conducive situation to gradually becoming an adult. Various acts of violence, both physically and psychologically prohibited and, as far as possible, be kept away from children, so they can grow and develop properly. It is stated clearly in the provisions of Article 9 of Law Number 35/2014 concerning Child Protection. First, every child has the right to receive education and teaching in the context of his personal development and level of intelligence according to his interests and talents. Second, every child has the right to get protection in the education unit from sexual crimes and violence committed by educators, instructional staff, fellow students, and/or other parties.

Norms in Article 9 of Law Number 35/2014 are derived from the Convention on the Rights of the Child. For example, in Article 28 number (2), it is very clearly emphasized

40 The analysis of criminal perspective on physical punishment for students can be read in Rusmilawati Windari, supra note 32.

41 Saihu Taufik, Perlindungan Hukum Bagi Guru, (2019) 5:1 Al Amin: Jurnal Kajian Ilmu Dan Budaya Islam, at 49-58. 
that schools promote ways of discipline without violence. It was later confirmed in the Committee's General Comment No. 8 on the Rights of the Child, which reads as follows: "addressing the widespread acceptance or tolerate corporal punishment of children and eliminating it, in the family, schools and other settings, is not only an obligation of States parties under the Convention. It is also a key strategy for reducing and preventing all forms of violence in societies".

In General Comment No. 13 (2011), the Convention on the Rights of the Child has also stated that giving physical punishment to children in any environment is a form of violence against children. Physical violence in the comments of the convention is not limited to violence that has fatal consequences, but also includes violence that is not fatal (non-fatal violence). Besides, Article 19 number (1) and Article 877 (a) are reiterated more specifically that each participating country must guarantee that no child shall be subjected to torture or other cruel, inhuman, or degrading treatment or punishment.

Changes in the cultural and legal landscape are sometimes not realized by many groups, including in schools. Some schools still have not changed in applying the culture and rules for their students, so they were shocked when applying the school's rules and culture with the old standard experienced a reaction from the wider community. Arifuddin ${ }^{42}$ strongly suggests that a multicultural approach in the education process in the school is a crucial factor in solving the clash of culture in the school by adding the human rights values into the lesson.

On the other hand, strong community control through social media. The presence of social media, in many versions, has changed the social order radically. In this social era, goodness is easily spread to the public, and vice versa, false or misleading content hoaxes, rumors, conspiracy theories, fabricated reports, click-bait headlines, and even satire, ${ }^{43}$ easily spread ugliness. In the midst of that, a lot of bad hands that act as influencers to lift or drop anyone he wants. In many cases of school violence, the spread is swift and massive to the public through social media, causing cynical public ${ }^{44}$ perceptions that lead to the growth of reactive attitudes towards the perpetrators or institutions where the perpetrators of violence situate. The example is from what is disclosed by Muhammad Nur Rizal as follows:

"The rise of juvenile delinquency in teachers is getting stronger because of social media factors that easily spread the violation. So paradoxically for students who have problems become more willing to bullying their teachers. and deterrent". 45

42 Iis Arifudin, 'Urgensi Implementasi Pendidikan Multikultural Di Sekolah', INSANIA : Jurnal Pemikiran Alternatif Kependidikan, (1970) 12:2 220-33.

43 See the analyses from Chengcheng Shao et al, 'The Spread of Fake News by Social Bots', Nature Communications, (2018) 9:1 1-16.

44 Damanik, supra note 29.

45 Republika.co.id, Kasus Kekerasan Terhadap Guru Kesalahan Sistemis, (2019), online: 〈https://www.republika.co.id/berita/pendidikan/eduaction/19/02/13/pmuwyp291-kasus-kekerasanterhadap-guru-kesalahan-sistemis>. 
Additionally, there is a subsequent moral decline that afflicts teachers, students, and parents of students. Teachers today compared to teachers in the past are recognized to have several very subtle differences. ${ }^{46}$ These differences can be seen from several factors; for example, in terms of education levels, teachers are now on average an education degree and have an educator certificate. In contrast, teachers in the past were on average alumni of Teacher Education Schools (SPG) or the like. It shows that the current academic qualifications of teachers are higher than those of past teachers.

In addition, today's teachers face situations and challenges of a society that are far more complex and advanced in all aspects, education, economics, technology, and social behavior. Simultaneously, teachers in the past tended to only deal with the times of the people characterized by "agrarian" with customs that are still strong. There are many more differences between the two. The contrast between the two most striking in the present context is the context of the appreciation of the teaching profession by the two different generations of teachers. Teachers in the past were influential in their educators' spirit and mentality despite the lack of academic competence.

In contrast, teachers at present are more prominent in their academic abilities and slightly less in the soul of their educators. This situation naturally gives birth to different attitudes and behaviors of teachers towards students. Psyche encourages teachers respected not only by students but also by parents of students and most people. At the same time, teachers today have decreased authority in front of students, parents, and the community so that this situation results in a negative response against teachers in enforcing discipline towards their students. The condition of parents today compounds it. Parents tend to have a less influential figure against their children, which may be caused by the parent's lack of role as figures of parents. It happened due to various reasons, such as the parent's business and children's distraction from social media, which lowers the family interactions.

\section{B. A Way to Strengthening the Protection of Teachers}

According to Article 41 of Government Regulation Number 74/2008 concerning Teachers, teachers are entitled to legal protection from acts of violence, threats, discriminatory treatment, intimidation, or unfair treatment from parties students, parents of students, community, bureaucracy, or other parties. The party who can legally guarantee the teacher in carrying out his profession is the government and several relevant stakeholders. Teachers are entitled to protection in carrying out their duties in the form of a sense of security and safety guarantees from the Government, Regional Governments, educational units, Teacher Professional Organizations, and/or the Community under their respective authorities. However, the question is how technically the provision of legal protection guarantees to teachers who are forced to deal with the law when disciplining their students has no clear provisions yet. In fact, in many cases, the teacher must try alone and at their own expense when dealing with the law.

46 See Iis Arifuddin, supra note 42. 
In facing this situation, two paths can be taken to provide legal assistance for teachers dealing with the law - as a form of legal protection. First, teachers can be given legal assistance by the Regional Government through legal assistance schemes managed by the legal department at the regency or city level or the Legal Bureau at the Provincial level. The legal aid is outlined in Law Number 16/201l concerning Legal Aid. Technically, the Regional Government does not directly practice in court, but a partnership with accredited legal aid providers. Second, through the teacher professional association.

In this regard, teacher associations can collaborate with law enforcement authorities to implement a code of ethics in handling teacher cases that consider exceeding the limits of reasonableness in disciplining their students, thus negatively impacting. For example, in Article 9 of the Teacher Code of Ethics is explained: (1) Providing recommendations for sanctions against teachers who violate the Indonesian Teacher Code of Ethics is the authority of the Indonesian Teachers Honorary Board. Furthermore, Article 9 Paragraph (6) states: "Any violation may carry out self-defense with/or without the assistance of professional teacher organizations and/or legal advisors under the types of violations committed before the Indonesian Teachers Honorary Board." Third, teachers who have the status of civil servants can also request rocks from the Legal Aid Institute for the Indonesian Civil Servants Corps (Korpri) to serve the interests of civil servants who conflict with the law.

\section{CONCLUSION}

Challenges of teachers in carrying out their profession today mostly centered on the issue of discipline rules enforcement. Teachers are often feeling doubtful to do their authority to educated student's character by using corporal punishment. It is as a result of the enactment of Child Law 35/2014, which sufficiently protects the child from any form of harm. In some cases, the parent or society uses the law to charge the teacher to the police. As a consequence, the rise of cases of violence against teachers which partially led to the emergence of legal problems for teachers, in this case, criminal charges. This fact demonstrates a contradiction norm between law on teacher protection and the child law. To this situation, this paper recommends norms harmonization between both laws. In a practical aspect, it suggests strengthening human rights awareness and child protection knowledge for teachers, which clearly prohibits the use of violence in disciplining students at school. Also, the presence of social media has had a profound effect on social life, which is rapidly spreading all forms of teacher behavior - the good and the bad get a large portion of it to spread in the community. Regarding this, the teacher association can work together with legal institutions to strengthen teachers' capacity on the rules of law and human rights, so they can avoid legal problems in carrying out their profession. If forced to deal with the law, then it can ask for legal assistance from legal aid providers or professional teacher associations to conduct an MoU with law enforcement officials to resolve it through a teacher code of ethics mechanism. 


\section{ACKNOWLEDGMENTS}

None.

\section{COMPETING INTERESTS}

The authors declare that they have no competing interests.

\section{REFERENCES}

Abdurrahman Assegaf. Pendidikan Tanpa Kekerasan: Tipologi, Kondisi, Kasus dan Konsep. (Yogyakarta: Tiara Wacana Yogyakarta, 2004).

Abd. Rachman Assegaf, et al. Kondisi dan Pemicu di Lingkungan Pendidikan. (2003) 2:1 IstiशRO'.

Abd Rachman Assegaf. Kondisi Dan Pemicu Kekerasan dalam Pendidikan, (2003) 2:1 Istiqro.

Agus Affandi. Dampak Pemberlakuan Undang-Undang Perlindungan Anak Terhadap Guru Dalam Mendidik Siswa. (2016) 11:2 Jurnal Hukum Samudra Keadilan.

Barda Nawawi Arief. Konsepsi Ajaran sifat Melawan Hukum Materiel dalam Hukum Pidana. (2004) Makalah Seminar Nasional di Hotel Patrajasa, Semarang, 6-7 May.

BBC.com, "Kekerasan Terhadap Siswa Masih Marak, Guru Berdalih 'Demi Kedisiplinan" (2018) online:〈https://www.bbc.com/indonesia/indonesia-44925805〉.

Beritagar.id, "2 Faktor Penyebab Kekerasan di Sekolah Menurut KPAI" (2019) online: 〈https://beritagar.id/artikel/berita/2-faktor-penyebab-kekerasan-di-sekolahmenurut-kpai>.

Beritagar.id, "Ketika Guru Menyuruh Murid Menjilat Kamar Mandi" (2018) online: 〈https://beritagar.id/artikel/berita/ketika-guru-menyuruh-murid-menjilatkamar-mandi>.

Brillio.net, "Benarkah Guru Pukul Murid itu Melanggar Undang-Undang? Ini Jawabannya" (2016) online: 〈https://www.brilio.net/serius/benarkah-guru-pukul-murid-itu-melang gar-undang-undang-ini-jawabannya-160812f.html?.

Chengcheng Shao et al. The Spread of Fake News by Social Bots. (2018) 9:1 Nature Communications.

Dasma Alfriani Damanik. Kekerasan Dalam Dunia Pendidikan: Tinjauan Sosiologi Pendidikan. (2019) 5:1 Jurnal Sosiologi Nusantara.

David R. Dupper, Amy E. Montgomery Dingus. Corporal Punishment in U.S. Public Schools: A Continuing Challenge for School Social Workers, (2008) 30:4 Children «Schools.

Doriane Lambelet Coleman et al. Where and How to Draw the Line Between Reasonable Corporal Punishment and Abuse, (2010) 73 Law and Contemporary Problems.

E. Gudyanga. Corporal Punishment in Schools: Issues and Challenges. (2014) 5:9 Mediterranean Journal of Social Sciences. 
Harun. Perlindungan Hukum Profesi Guru Dalam Perspektif Hukum Positif. (2016) l:1 Jurnal Law and Justice.

Iis Arifudin. Urgensi Implementasi Pendidikan Multikultural di Sekolah. (1970) 2:1 INSANIA: Jurnal Pemikiran Alternatif Kependidikan.

Indriyanto Seno Adji. Asas Perbuatan Melawan Hukum Materiel dan Masalahnya dalam Perspektif Pidana di Indonesia. (2004) Makalah Seminar Nasional Tentang AsasAsas Hukum Pidana Nasional, Semarang, 26-27 May.

J.P. Bourke. Bourkes' Criminal Law, (Sydney: Butterworth's, 1981).

Johan Galtung. Kekuasaan dan Kekerasan. (Yogyakarta: Kanisius, 1992).

KPAI. Data Kasus Perlindungan Anak Berdasarkan Lokasi Pengaduan Dan Pemantauan Media Se-Indonesia Tahun 2011-2016. (2016) Series.

Margaretha Hanita, et.al. Pencegahan Kekerasan Terhadap Anak di Lingkungan Pendidikan.

(Jakarta: Pusat Pelayanan Terpadu Pemberdayaan Perempuan dan Anak (P2TP2A) Provinsi DKI Jakarta, 2009).

Martias G.I.R.M. Pembahasan Hukum: Penjelasan Istilah-Istilah Hukum Belanda-Indonesia. (Jakarta: Ghalia Indonesia, 1969).

Merdeka.com, "Guru SMPN 10 Yogyakarta Mengaku Emosi dan Spontan Tendang Siswanya" (2019) online: 〈https://www.merdeka.com/peristiwa/guru-smpn-10yogyakarta-mengaku-emosi-dan-spontan-tendang-siswanya-html .

Muchsin. Perlindungan dan Kepastian Hukum bagi Investor di Indonesia. (Surakarta: magister Ilmu Hukum Program Pascasarjana Universitas Sebelas Maret, 2003).

Phillipus M. Hadjon. Perlindungan Hukum Bagi Rakyat Indonesia. (Surabaya: PT. Bina Ilmu, 1987).

R.A. Dubanoski, Inaba, M., \& Gerkewicz, K. Corporal Punishment in Schools: Myths, Problems and Alternatives. (1983) 7:3 Child Abuse \& Neglect.

R.M. Youssef, Attia, M. S.-E.-D., \& Kamel, M. I. Children Experiencing Violence II: Prevalence and Determinants of Corporal Punishment in Schools. (1998) 22:10 Child Abuse \& Neglect.

Republika.co.id, "Kasus Kekerasan Terhadap Guru Kesalahan Sistemis" (2019) online: 〈https://www.republika.co.id/berita/pendidikan/eduaction/19/02/13/pmuwyp29 1-kasus-kekerasan-terhadap-guru-kesalahan-sistemis〉.

Rurrotul Ainiyah. Pandangan Masyarakat Terhadap Kekerasan Dalam Pendidikan Terkait Dengan Konsep Tawadhu' Terhadap Guru di MTs An Namirah Tanah Merah Bangkalan, (2013).

Rusmilawati Windari. Penggunaan Hukuman Disiplin (Corporal Punishment) di Lingkungan Sekolah dalam Perspektif Hukum Pidana Indonesia. (2015) 4:3 Jurnal Hukum Prioris.

Saihu Taufik. Perlindungan Hukum Bagi Guru. (2019) 5:1 Al Amin: Jurnal Kajian Ilmu dan Budaya Islam.

Satijipto Raharjo. Ilmu Hukum. (Bandung: PT. Citra Aditya Bakti, 2000).

Setiono. Rule of Law (Supremasi Hukum). (Surakarta: Magister Ilmu Hukum Program Pascasarjana Universitas Sebelas Maret, 2004). 
Simomot, "Kisah Lengkap Guru Muhammad Samhudi Diadili Gara-Gara Ada Bekas Cubitan di Lengan Muridnya" (2016) online: 〈https://simomot.com/2016/07/01/kisah-lengkapguru-muhammad-samhudi-diadili-gara-gara-ada-bekas-cubitan-di-lenganmuridnya-2/〉〈https://www.liputan6.com/regional/read/2578217/samhudi-gurucubit-murid-tetap-mengajar».

Suara.com, "KPAI: Pelaku Kekerasan Seksual Didominasi Guru dan Kepala Sekolah" (2019) online: 〈https://www.suara.com/news/2019/06/30/214134/kpai-pelaku-kekeras an-seksual-ke-siswa-didominasi-guru-dan-kepala-sekolah>.

Tamsil Muis, Muhammad Syafiq, dan Siti Ina Savira. Bentuk, Penyebab, dan Dampak dari Tindak Kekerasan Guru Terhadap Siswa Dalam Interaksi Belajar Mengajar dari Perspektif Siswa di SMPN Kota Surabaya: Sebuah Survey. (2011) 1:2 Jurnal Psikologi Teori dan Terapan.

Tempo.co, "KPAI: Kekerasan di Dunia Pendidikan Mencapai 127 Kasus" (2019) online: 〈https://nasional.tempo.co/read/1266367/kpai-kekerasan-di-dunia-pendidikanmencapai-127-kasus/full\&eview=ok>. 
136 | Challenges for Teacher Profession in Contemporary Indonesia: A Regulatory Analysis

This page is intentionally left blank 